AGREGAT: Jurnal Ekonomi dan Bisnis

Vol. 3, No. 2, September 2019

http://journal.uhamka.ac.id/index.php/agregat

p-ISSN: 2549-5658 e-ISSN: 2549-7243

DOI: 10.22236/agregat_vol3/is2pp191-204

Pp 191-204

\title{
THE EFFECT OF USD/IDR EXCHANGE RATE, INTEREST RATE, AND WORLD OIL PRICE TO JAKARTA COMPOSITE INDEX (JCI)
}

\author{
Ummu Salma Al-Azizah ${ }^{1}$, Yusdi Daulay ${ }^{2}$, Naufal Krisnanto ${ }^{3}$ \\ 1,2,3 University of Muhammadiyah Prof. DR. HAMKA \\ Email: ummusalma@uhamka.ac.id
}

Received: October 30, 2018; Revised: May 16, 2019; Accepted: June 28, 2019

\begin{abstract}
This research aims to investigate effect of selected macroeconomic variables, i.e., USD/IDR exchange rate, interest rate, and world oil price to indonesia composite index at the indonesia stock exchange (IDX). This paper examine the direct effect of selected macroecomonic variable on Indonesia Composite Index. The study used time series data from the 2012-2017. By using an regression technique analysis, the result from showed that simultaneously the exchange rate, interest rate, and world oil price have a significant effect on Indonesia Composite Index. Partially, only the exchange rate has a significant effect on Indonesia Composite Index, interest rate and world oil price have no significant effect on Indonesia Composite Iindex. The amount of influece caused by the three variables is $58 \%$ and the rest is explained by other variables.
\end{abstract}

Keywords: Capital Market, Jakarta Composite Index (JCI). Exchange Rate, Interest Rate, World Oil Price

\footnotetext{
Abstrak

Penelitian ini bertujuan untuk mengetahui pengaruh variabel makroekonomi terpilih, yaitu, nilai tukar USD / IDR, suku bunga, dan harga minyak dunia terhadap indeks komposit indonesia di bursa efek indonesia (BEI). Makalah ini menguji pengaruh langsung dari variabel makro elektronik terpilih pada Indeks Komposit Indonesia. Penelitian ini menggunakan data deret waktu dari 2012-2017. Dengan menggunakan analisis teknik regresi, hasil dari penelitian menunjukkan bahwa secara simultan nilai tukar, suku bunga, dan harga minyak dunia berpengaruh signifikan terhadap Indeks Harga Saham Gabungan. Secara parsial, hanya nilai tukar yang berpengaruh signifikan terhadap Indeks Harga Saham Gabungan, tingkat suku bunga dan harga minyak dunia tidak berpengaruh signifikan terhadap Indeks Harga Saham Gabungan Indonesia. Jumlah pengaruh yang disebabkan oleh tiga variabel adalah 58\% dan sisanya dijelaskan oleh variabel lain. Kata Kunci: Pasar Modal, Jakarta Composite Index (JCI). Nilai Tukar, Suku Bunga, Harga Minyak Dunia
} 


\section{INTRODUCTION}

The capital market is an important factor in economy in a particular in Indonesia. Capital market have to important functions in the economy, namely to be a means for companies fhat want to have additional sources of capital for operational continuity and other activities that provide profits to companies by expanding, developing bussiness or as a place for investors who have excess funds and want to invest in the form of instruments that are in the capital market in order to get more profits than just saving in the bank (Ardian, 2010).

The Capital Market is a place where the activities of various types of securities are traded, where his meeting places parties who need funding and the excess of fund. In Chapter 1 Article 1 of Capital Market Law no. 9/1995 on general provisions defining the common stock and the effect was largely as a party that organizes and provides system and or the means to carry out delas buy and sell securities other parties with the purpose to trade securities among themselves. While the effect are securities, namely debt instruments, commercial paper, stocks, bonds, proof of the debt, investment units of collective investment, futures contracts on securities and any derivative of effect.

Capital Market is a place where various parties, especially companies sell stocks and bonds with the purpose of the selling results will be used as an additional fund or to strengthen the company (Fahmi, 2011). Composite Stock Price Index is a combination of the prices of securities listed company in Indonesia Stock Exchange. Composite index is an index showing the general movement of stock prices listed on the stock exchange is the reference of the development of activities in the capital market. Composite index can be used to assess the general market situation or measure if the stock price has increased or decreased (Anoraga \& Pakarti, 2001) Composite Index is a stock price index figures already compiled and calculated by producing trend, where the index number is a number that are processed in such a way that can be used to compare events that can be changes in stock prices over time (Jogiyanto, 2013).

Currency exchange rate indicates if the price of the currency exchanged for another currency. Determining the value of a country's currency exchange rates with other 
Ummu Salma Al-Azizah 193

currencies is determined as well as the goods which are the demand and supply of the currency in question. This law also applies to the rupiah exchange rate, if demand would cent more than supply the rupiah exchange rate will appreciate, and vice versa. Exchange rate is the price of a currency relative to the currencies of other countries (Ekananda, 2014). According Nopirin (2008) argues that if all other conditions remain, the depreciation of the currency of a country against all other currencies led to its exports cheaper and its imports more expensive. While the appreciation made exports more expensive and imports cheaper. According Kuncoro (2001) shows the exchange rate when the price of the currency

exchanged for another currency. Determining the value of a country's currency exchange rate moved at another country's currency is determined as to which any goods, ie by the demand and supply of the currency in question.

Interest rate is the price of the use of money for a certain period of time or the price of the use of money which is used at the moment and will dikembali right at a future time. Interest rate is the ratio of return on a number of investments as a form of reward given to investors (Husnan, 2009).
Interest rate is the price of a loan. Interest rates are expressed as a percentage of money from the principal per unit of time. the interest rate is a measure of the price of the resources used by the debtor to be paid to creditors (Sunariyah, 2011). According to Boediono (1994) the interest rate is one indicator in determining whether someone will make an investment or saving.

The relationship between oil prices, exchange rates and stock prices has received considerable attention from academicians and practitioners globally. It is widely accepted that oil is an important part of the economic development of all countries across the globe, especially the emerging economies which account for more than a half of world total oil consumption (Pershin et al., 2016). In particular, oil is considered as a leading indicator of exchange rate movements since an increase in oil price reduces the wealth of oil-importing nations by transfering their income to oil exporting nations through trade balande (Turhan et al, 2014). Examining the oil-stock market realtionship is important for asset allocation and portofolio risk management since investors decision are based not only on the available fundamental information in the stock markets but also on the information 
194AGREGAT: Jurnal Ekonomi dan Bisnis

Vol. 3, No. 2, September 2019

http://journal.uhamka.ac.id/index.php/agregat

p-ISSN: 2549-5658 e-ISSN: 2549-7243

DOI: 10.22236/agregat_vol3/is2pp191-204

Hal 191-204

prevailing in the oil markets (Mensi et al,

investor to invest. In particular, oil is 2017). Investors have to maintain their considered as a leading indicator of exchange purchasing power in inflationaryperiod and in the periods of exchange rates fluctiation and hence, they move towards precious metals market and hedge their portofolios with the purpose of saving their purchasing power (Gaur and Bansal, 2010).

Since monetary policy tools are used to stabilize the economy and hence poliycy makers are interested to understand the changes that are considered sensitive with respect to their objectives. Interest rate is the important monetary policy tool that is decided by the monetary authorities while considering inflation, investment level and fluctuations of exchange rate which have direct links with domestic gold price (M. Akbar et al, 2019).

The index that is very often noticed by investors when investing in Indonesia is the Composite Stock Price Index (Yosep, 2014). This is because this index contains all shares listed on the Indonesia Stock Exchange. Therefore, investors can see the condition of an existing capital market in Indonesia by looking at the developments of the JCI. Of course this can be a fundamental basis for an 
Ummu Salma Al-Azizah 195

between precious metals' prices, exchange rate and oil price. Ismail (2009) reveals that exchange rate, inflation, money supply and stock market index have significant impact upon gold price but gold price does not affect these variables. Sujit and Kumar (2011) prove that gold price significantly affect different exchange rates but exchange rates have no effect upon gold prices.

Yahyazadehfar and Babaie (2012) demonstrates that house price, interest rate, gold price and stock market return in Iran have only short-run effects upon each other. Hussain et al. (2013) found bi-directional association among stock returns and oil price in Malaya. Jain and Ghosh (2013) shows casual linkages among global oil prices, precious metals and Indian rupee-US dollar. The study concluded that exchange rate does not granger cause gold price. Sinton (2014) finds that there is no long-run association among gold price, stock price and exchange rate in Indonesia. Bhunia and Pakira (2014) found no causal relationship among stock market and gold price as well as among exchange rate and stock-market whereas bidirectional association was found among gold price and exchange rate in India.

Srinivasan and Prakasam (2015) investigated casual relationship among stock price, gold price and foreign exchange rate in India by applying ARDL approach. The study found long-run relationship of gold price and stock price with exchange rate but no indication of cointegration and causality among stock price and gold price. Investigated the effect of exchange rate, interest rate and world price oil on the stock pric in Indonesia (Reshinta Candra Gumilang et al, 2014).

Using multiple regression studies, they found that exchange rate, interest rate, and world price oil have a negative effect and have significant effect on the stock price in Indonesia. Ronald Pratama Poetra et al. (2014) examine the effect of inflation, world price oil, interest rate and exchnge rate on the stock price in Indonesia. Using multiple regression studies, the resullt show that a world price oil and interest rate did not have a signifant effect on stock price. The exchange rate have a significant effect on stock price in Indonesia. Pasrun Adam et al. (2015) investigated relationship between world crude oil and the stock market in Indonesia. Using LVAR causal model, the research show that the world crude oil have a positive effect on composite stock index at the Indonesia stock exchange. This study has a benefit for capital market investors who 
196AGREGAT: Jurnal Ekonomi dan Bisnis

Vol. 3, No. 2, September 2019

http://journal.uhamka.ac.id/index.php/agregat

p-ISSN: 2549-5658 e-ISSN: 2549-7243

DOI: 10.22236/agregat_vol3/is2pp191-204

Hal 191-204

want to invest in the capital market in Indonesia. They can consider various macroeconomic factor such as exchange rate, interest rate and world price because based on the results of this study. And then, this study looking for the differences that occur from the theory of exchange rate, interest rate and world price oil on the composite stock index in Indonesia).

\section{RESEARCH METHOD}

This Study used the secondary data in which the population and sample in this study are the monthly data for exchange rate, interest rate, world oil price and stock price in Indonesia In the years 2012-2017. The data in this study was the time series data with the sampling technique used purposive sampling method. The data of the Jakarta composite index was obtained from the Indonesia stock exchange (www.idx.co.id) . The data of exchange rate and interest rate were obtained from website (finance.yahoo.com). The data of world oil price was obtained from website (www.economagic.com).

There are two methods of calculating the Composite Index commonly used in Indonesia:

1. Average Method
A method in which the stock market price include in this index are summed and then divided by the divisor factor.

$\mathrm{JCI}=\stackrel{\Sigma_{2}}{ }$

Information :

JCI : Jakarta Composite

Index

$\Sigma_{2} \quad:$ Total Share Price

Divisor : Basic Stock Price

2. Weighted Average Method

A method that adds weight in the index calculation in addition to the market price of the shares that are listed and the basic price of the stock. The weighting is done in the calculation of the index in general is the number of shares issued. There are two methods for calculating the weighted average method :

a. Paasche

This method compares the market capitalization of all stocks with the base value of all the sharps that depend on an index. In this case the greater the capitalization of a stock, it will cause a very large effect if there is a change in the price of the shares in question.

$$
\mathrm{JCI}=\longleftarrow
$$

Information : 
Ummu Salma Al-Azizah 197

: Stock Price Currently

: Shares Outstanding

\section{: Basic Stock Price}

\section{b. Laspeyres}

This method uses the number of shares issued on the base day and does not change forever even though there are new shares issued.

Indeks $=\frac{\Sigma(\curvearrowright)}{2}$

: Stock Price Currently

0 : Number of initial stock

: Basic Stock Price.

Based on the theory presented above, it can be concluded that the Composite Index is an index that can measure how the performance of the capital markets in Indonesia, and may be the fundamental basis for companies or investors who becomes a role in the Indonesian capital market.

Foreign exchange rates will change according to changes in foreign exchange demand and supply. Demand for foreign exchange is needed to make payments abroad (imports), which are in the form of international balance of payments transactions. A currency is said to be strong if a credit transaction is greater than a debit transaction, or in other words a surplus in the balance of payments. Instead the value of a currency is said to be weak if the balance of payments deficit, or be notarized if the foreign exchange demand exceeds the supply of foreign exchange (Nopirin, 2008). Ekananda (2014:201) value of exchange rate can measure with:

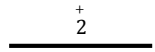

Keterangan :

$\mathrm{Kb}=$ Selling Rate $\mathrm{Kj}=$ Buying Rate.

\begin{tabular}{|l|l|}
\hline Operational Variables \\
\hline Exchange Rate & $\begin{array}{l}\text { The ratio the end } \\
\text { monthly value of } \\
\text { exchange rate. }\end{array}$ \\
\hline Interest Rate & $\begin{array}{l}\text { The ratio the end } \\
\text { monthly value of } \\
\text { interest rate. }\end{array}$ \\
\hline World Oil Price & $\begin{array}{l}\text { The ratio the end } \\
\text { monthly value of } \\
\text { interest rate. }\end{array}$ \\
\hline JCI & $\begin{array}{l}\text { The ratio the end } \\
\text { monthly value of } \\
\text { interest rate. }\end{array}$ \\
\hline
\end{tabular}

JCI : Jakarta Composite Index

The method used in this research is a descriptive statistics, multiple linear regression analysis, the classical assumption, hypothesis testing, $\mathrm{T}$ test, F-test, and analysis of correlation coefficients by using E-Views 10 .

\section{RESULTS AND DISCUSSION}

Based on the Table 1, the highest stock index from the year 2012-2017 was in Desember 2017 amounted to 6605,631, while the lowest was in April 2012 by 3832,824. And then 
198AGREGAT: Jurnal Ekonomi dan Bisnis

Vol. 3, No. 2, September 2019

http://journal.uhamka.ac.id/index.php/agregat

p-ISSN: 2549-5658 e-ISSN: 2549-7243

DOI: 10.22236/agregat_vol3/is2pp191-204

Hal 191-204

average of JCI is 4934,123 with a standard

deviation of 604,1132 , its mean the value of JCI

fluctuate sharply.

\section{Table 1 : Descriptive Statistics of JCI}

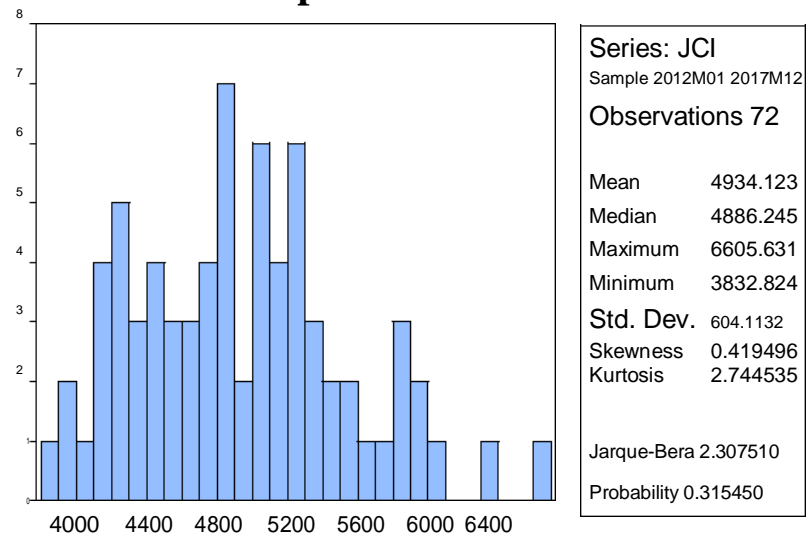

Based on the Table 2, the highest exchange rate from the year 2012-2017 was in September 2015 amounted to 14689, while the

lowest was in Januari 2012 by 8980 . And then average of exchange rate is 12001,51 with a standard deviation of 1665 , its mean the value of exchange rate fluctuate sharply.

Table 2 : Descriptive Statistics of Exchange Rate
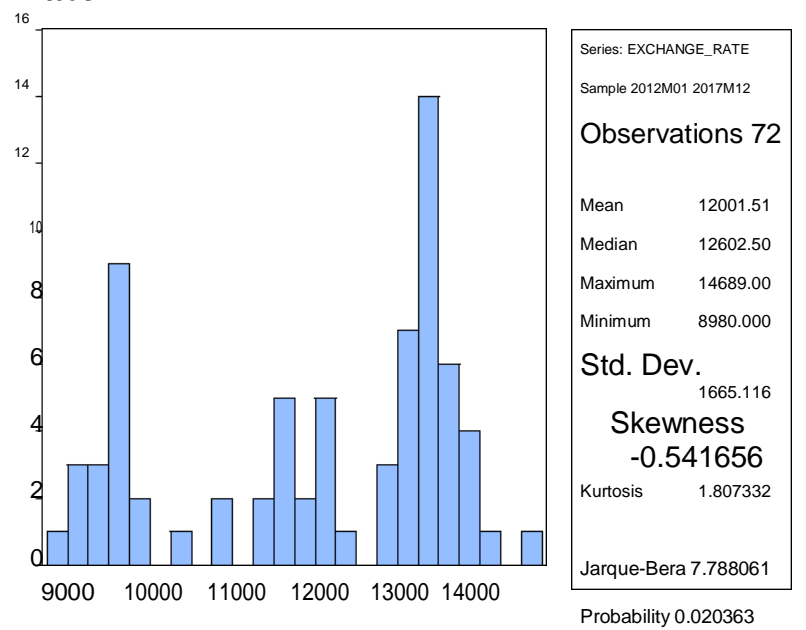

Based on the Table 3, the highest interest rate from the year 2012-2017 was in November 2014 amounted to $7,75 \%$, while the lowest was in September 2017 - Desember 2017 by $4,25 \%$. And then average of interest rate is $6,39 \%$ with a standard deviation of 1,161 , its mean the value of interest rate relative stable.

\section{Table 3 : Descriptive Statistics of} Interest Rate

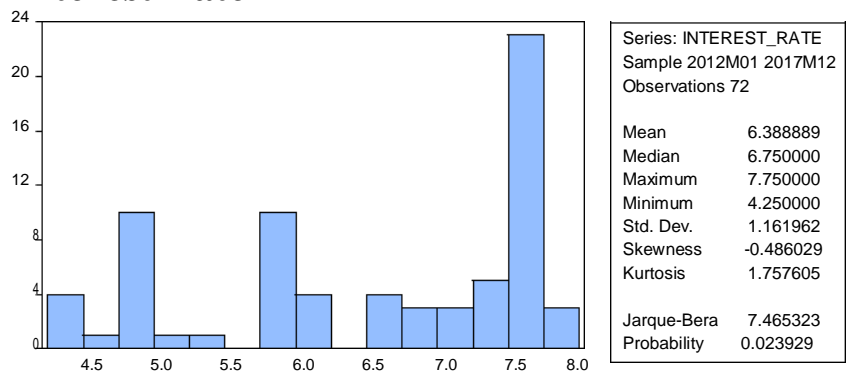

Based on the Table 4, the highest world oil price from the year 2012-2017 was in Agustus 2013 amounted to 106,57\$, while the lowest was in Februari 2016 by 30,32\$. And then average of world oil price is $77,77 \$$ with a standard deviation of 25,25 , its mean the value of world price oil relative stable

Table 4 : Descriptive Statistics of World Oil Price

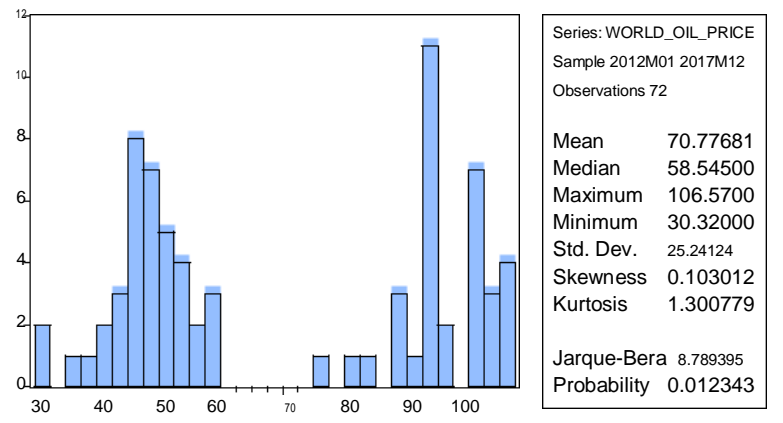


Ummu Salma Al-Azizah 199

Based on the Table 7 , it is found that

Based on the Table 5, this study has a normal distribution, seen from a probability value $(0,434$ or $43 \%)$ that exceed 0,05 or $5 \%$. This regression model can be used because it fulfilling the assumption of normality test.

\section{Table 5 : Normality Test}

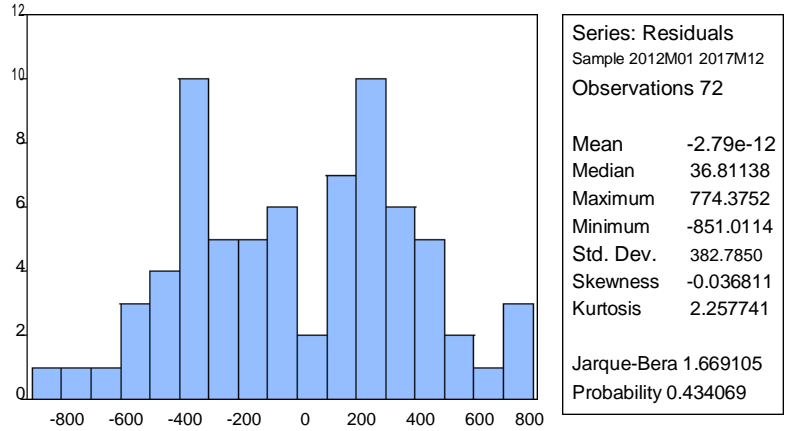

Based on the Table 6 , it is found that value of correlation between variables nothing exceed 0,8 and Value of Inflation Factor on all variables below 0,10 so that it can be said that there is no multicollinearity among the independent variable.

\section{Table 6 : Multicollinearity Test}

\begin{tabular}{|c|c|c|c|c|c|}
\hline \multicolumn{6}{|c|}{$\begin{array}{l}\text { Variance Inflation Factors } \\
\text { Date: } 05 / 22 / 19 \text { Time: } 22: 51 \\
\text { Sample: } 2012 \mathrm{M} 012017 \mathrm{M} 12 \\
\text { Included observations: } 72\end{array}$} \\
\hline \multicolumn{2}{|c|}{ Variable } & \multicolumn{2}{|c|}{$\begin{array}{l}\text { Coefficient } \\
\text { Variance }\end{array}$} & $\begin{array}{l}\text { Uncentered } \\
\text { VIF }\end{array}$ & $\begin{array}{l}\text { Centered } \\
\text { VIF }\end{array}$ \\
\hline \multirow{4}{*}{\multicolumn{2}{|c|}{$\begin{array}{l}\text { EXCHANGE_RATE } \\
\text { INTEREST_RATE } \\
\text { WORLD_OIL_PRICE } \\
\text { C }\end{array}$}} & \multirow{4}{*}{\multicolumn{2}{|c|}{$\begin{array}{l}0.002332 \\
1733.297 \\
10.57183 \\
585731.3\end{array}$}} & 161.0474 & 3.000061 \\
\hline & & & & \multirow{2}{*}{$\begin{array}{l}34.38244 \\
28.04916\end{array}$} & 1.086066 \\
\hline & & & & & 3.125869 \\
\hline & & & & 275.6587 & NA \\
\hline \multicolumn{6}{|c|}{ Correlation } \\
\hline & \multicolumn{2}{|c|}{ EXCHANGE... } & \multicolumn{2}{|c|}{ INTEREST_... } & WORLD_OI... \\
\hline EXCHANGE... & \multicolumn{2}{|c|}{1.000000} & \multicolumn{2}{|c|}{-0.056829} & -0.808503 \\
\hline INTEREST_... & \multicolumn{2}{|c|}{-0.056829} & \multicolumn{2}{|c|}{1.000000} & 0.208200 \\
\hline WORLD_OI... & \multicolumn{2}{|c|}{-0.808503} & \multicolumn{2}{|c|}{0.208200} & 1.000000 \\
\hline
\end{tabular}

value of probability from each independent variables above there is no significant or more than $5 \%$, which means there are no independent variables that affect the ARESID variable (Absolute Residual) so that it can be said that there is no heteroscedasticity on the research.

Table 7 : Heteroscedasticity Test : Glejser Heteroskedasticity Test: Glejser

\begin{tabular}{llll}
\hline \hline F-statistic & 0.941535 & Prob. F(3,68) & 0.4255 \\
Obs*R-squared & 2.871482 & Prob. Chi-Square(3) & 0.4119 \\
Scaled explained SS & 1.988160 & Prob. Chi-Square(3) & 0.5749
\end{tabular}
1988160 Prob. Chi-Square(3)

Test Equation:

Dependent Variable: ARESID

Method: Least Squares

Date: 05/22/19 Time: 23:08

Sample: 2012M01 2017M12

Included observations: 72

\begin{tabular}{lrlll}
\hline \hline \multicolumn{1}{c}{ Variable } & Coefficient & Std. Error & t-Statistic & Prob. \\
\hline \hline \multicolumn{1}{c}{ C } & 28.45775 & 387.0585 & 0.073523 & 0.9416 \\
EXCHANGE_RATE & 0.006452 & 0.024420 & 0.264227 & 0.7924 \\
$\quad$ INTEREST_RATE & 33.15577 & 21.05542 & 1.574691 & 0.1200 \\
WORLD_OIL_PRICE & 0.110873 & 1.644381 & 0.067425 & 0.9464 \\
\hline \hline R-squared & 0.039882 & Mean dependent var & 325.5729 \\
Adjusted R-squared & -0.002476 & S.D. dependent var & 197.5695 \\
S.E. of regression & 197.8140 & Akaike info criterion & 13.46648 \\
Sum squared resid & 2660865. & Schwarz criterion & 13.59297 \\
Log likelihood & -480.7934 & Hannan-Quinn criter. & 13.51684 \\
F-statistic & 0.941535 & Durbin-Watson stat & 0.852358 \\
Prob(F-statistic) & 0.425533 & & & \\
\hline \hline
\end{tabular}

Based on Table 8 , it is found that the probability for the Breusch-Godfrey LM Test is $0,53>0,05$ so that it can be said that there is no autocorrelation in the research variables.

\section{Table 8 : Autocorrelation Test}

Breusch-Godfrey Serial Correlation LM Test:

\begin{tabular}{llll}
\hline \hline F-statistic & 0.580272 & Prob. F(2,65) & 0.5626 \\
Obs*R-squared & 1.245435 & Prob. Chi-Square(2) & 0.5365
\end{tabular}


200AGREGAT: Jurnal Ekonomi dan Bisnis

Vol. 3, No. 2, September 2019

http://journal.uhamka.ac.id/index.php/agregat

p-ISSN: 2549-5658 e-ISSN: 2549-7243

DOI: 10.22236/agregat_vol3/is2pp191-204

Hal 191-204

Based on Table 9, the result of $\mathrm{T}$ test shows that exchange rate has the significant value of 0,000 and t-value $(5.44)>t$-table $(1,99210)$ with the value of regression coefficient of 0,263013 that shows positive effect. Thus, there is a negative and no significant effect of interest rate with $\mathrm{t}$ value $(-6.24)<$ t-table $(1,99210)$, value of regression coefficient of $-260,1213$. In another hand, world price oil has no significant with t-value $(1.342)<\mathrm{t}$-table $(1,99210)$, value of regression coefficient of 4,366161 that shows positive effect.

Based on Table 9. the result of $F$ test shows that exchange rate, interest rate, and world oil price has the significant effect simultaneously on JCI with value of probability $(0,00)<0,05$ and $\mathrm{F}$ value (33.78992) > F-Table $(3,12)$.

Based on Table 9, the result of value Adjusted $\mathrm{R}^{2}$ (0.580799) shows that exchange rate, interest rate, and world price oil was able to explain the dependent variable by $58 \%$ and the rest explained by other variables.

Table 9 : T Test, F Test, and Adjusted $\mathbf{R}^{2}$
Dependent Variable: $\mathrm{JCl}$ Method: Least Squares Date: 05/22/19 Time: $23: 10$ Sample: 2012M01 2017M12 Included observations: 72

\begin{tabular}{lrlrl}
\hline \hline \multicolumn{1}{c}{ Variable } & Coefficient & Std. Error & t-Statistic & Prob. \\
\hline \hline EXCHANGE_RATE & 0.263013 & 0.048286 & 5.446980 & 0.0000 \\
$\quad$ INTEREST_RATE & -260.1213 & 41.63289 & -6.247976 & 0.0000 \\
WORLD_OIL_PRICE & 4.366161 & 3.251435 & 1.342841 & 0.1838 \\
\multicolumn{1}{c}{ C } & 3130.435 & 765.3308 & 4.090303 & 0.0001 \\
\hline \hline R-squared & 0.598512 & Mean dependent var & 4934.123 \\
Adjusted R-squared & 0.580799 & S.D. dependent var & 604.1132 \\
S.E. of regression & 391.1376 & Akaike info criterion & 14.82995 \\
Sum squared resid & 10403228 & Schwarz criterion & 14.95643 \\
Log likelihood & -529.8782 & Hannan-Quinn criter. & 14.88030 \\
F-statistic & 33.78992 & Durbin-Watson stat & 0.254100 \\
Prob(F-statistic) & 0.000000 & & \\
\hline \hline
\end{tabular}

Exchange rate has a positive and significant effect on stock price index in Indonesia. On the other hands, interest rate has no significant effect and negative on stock price in Indonesia. And then, world price oil has a positive and no significant effect on stock price in Indonesia. Simultaneously, exchange rate, interest rate, and world price oil has a significant effect on stock price in Indonesia. Therefore the fluctuation of exchange rate influential on stock price in Indonesia, when interest rates rise, the composite index will also increase and then vice versa but it doesn't apply to interest rate and world price oil. However, fluctuate exchange rate, interest rate, and world price oil has a effect on composite index. When them increase or decrease, the composite index will also like that 
Ummu Salma Al-Azizah 201

CONCLUSION

The conclusion of this research are as follows

: (1) Based on the research results that the variable exchange rate has a significant positive influence on JCI, this means the increase in the exchange rate will push up the JCI in Indonesia. (2) Based on the research results that variable interest rates did not have a significant influence on JCI in Indonesia. This suggests that interest rate fluctuations do not affect the JCI in Indonesia, particularly in the period 2012-2017. (3) Based on the research results that the world oil price variables do not have significant influence terhadapn JCI. This shows that the world oil price movements do not affect the JCI in Indonesia, especially in tahin 2012-2017. (4) Based on the research results that simultaneously variable exchange rates, interest rates, and oil prices have a significant impact on JCI. This shows that the movement of these three variables can affect JCI though variable interest rates and oil prices partially no effect on JCI..

The implication of managerial policy which can be taken in this study is that capital market investor need to pay attention to exchange rate, interest rate, world oil price in Indonesia.
This study still has some limitation:

(1) This study only used exchange rate, interest rate and world price oil as variables that explain about macroeconomy and need more variable of that to make this research more accurate. (2) The data in this study were limited to the monthly data throughout 2012-2017 obtained in Indonesia and need more specific data as sample, as an example using data day by day or week by week to get results better than this study.

\section{REFERENCE}

Adam, P., Rianse, U., Cahyono, E., \& Rahim, M. (2015). Modeling of the dynamics relationship between world crude oil prices and the stock market in Indonesia. International Journal of Energy Economics and Policy, 5(2), 550-557.

Akbar, Muhammad., Farhan Iqbal., Farzana Noor. (2019). Bayesian analysis of dynamic linkages among gold price, exchange rate and interest rate in Pakistan. Journal Resources Policy (62), 154-164.

Anoraga, Pandji, dan Pakarti Piji, (2001). Pengantar Pasar Modal (Edisi Revisi). PT Asdo Mahasatya. 
282AGREGAT: Jurnal Ekonomi dan Bisnis

Vol. 3, No. 2, September 2019

http://journal.uhamka.ac.id/index.php/agregat

p-ISSN: 2549-5658 e-ISSN: 2549-7243

DOI: 10.22236/agregat_vol3/is2pp191-204

Hal 191-204

Apriansyah, Y., Prabawa, S. A., \& Kamaludin, K. (2014). Analisis Pengaruh Kurs (Usd/Idr), Suku Bunga Sertifikat Bank Indonesia (Sbi), Inflasi Dan Indek Nikkei 225 Terhadap Indeks Harga Saham Gabungan (Ihsg) Di Bursa Efek Indonesia (Bei) Periode Januari 2004Agustus 2013 (Doctoral dissertation, Universitas Bengkulu).

Beckers, S., Soenen, L.A., 1984. Gold options, an attractive investment instrument for the non-US investor-the case of the Belgian and Dutch investor. Economist 131 (1), 80-87.

Bhunia, A., Pakira, S., 2014. Investigating the impact of gold price and exchange rates on sensex: an evidence of India, Eur. J. Account. Finance Bus. 2 (1). 1-11.

Boediono. (1994). Ekonomi Moneter (Seri Sinopsis Pengantar Ilmu Ekonomi Nomor 2). BPFE : Yogyakarta.

Capie, F., Mills, T.C., Wood, G., 2005. Gold as a hedge againts the dollar. J. Int. Financ. Mark. Inst. Money 15 (4), 343-352

Ekananda. Mahyus. (2014)/ Ekonomi Internasional. Jakarta: Erlangga.

Gaur, A., Bansal, M., 2010. A comparative study of gold price movements in Indian and global markets. Indian J. Finance. 4 (2),32-37.

Gumilang, R. C. (2014). Pengaruh Variabel Makro Ekonomi, Harga Emas Dan Harga Minyak Dunia Terhadap Indeks Harga Saham Gabungan (Studi pada Bursa Efek Indonesia Periode 20092013). Jurnal Administrasi Bisnis, 14(2).

Han, A., Xu, S., Wang, S., 2008. Australian dollars exchange rate and gold prices: an interval method analysis. In: The 7th International Symposium on Operations Research and its Application, pp. 46-52.

Husnan, S. (2009). Dasar-dasar Teori Portofolio \& Analisis Sekuritas. Yogyakarta: UPP STIM YKPN.

Hussain, M.Y.M., Muhammad, F., Razak, A.A., Tha, G.P., Marwan, N., 2013. The link between gold price, oil price and Islamic stock market: experience from Malaysia. J. Stud. Soc. Sci. 4 (2), 161-182.

Irham, Fahmi. (2011). Analisa Laporan Keuangan.Bandung: Alfabeta. 
Ummu Salma Al-Azizah 203

Ismail, Y.S., 2009. Forecasting gold prices using multiple linear regression method. Am. J. Appl. Sci. 6 (8), 1509-1514.

Jain. A., Ghosh, S., 2013. Dynamics of global oil prices, gold price, exchange rate, and stock market in India. Resour. Pol. 49, 179-185.

Jogiyanto, Hartono. (2013). Teori Portofolio dan Analisis Investasi (Edisi Ke-8). Yogyakarta: BPFE Yogyakarta.

Kuncoro, Achmad. (2001). Cara Menggunakan dan Memaknai Analisis Asumsi Klasik. Bandung: Alfabeta.

Mensi, W., Hammoudeh, S., Shahzad, S.J.H., \&Shahbaz, M. (2017). Modeling systemic risk and dependence structure between oil and stock markets using a variational mode decomposition based copula method. Journal of Banking \& Finance, 75, 258-279.

Nopirin. 2008. Pengantar Ilmu Ekonomi

Makro \& Mikro (Edisi ke-1).

Yogyakarta: BPFE Yogyakarta.

Pershin, V., Molero, J.C., \& de Gracia, F.P. (2016).Exploring the oil prices and exchange rates nexus in some African economies. Journal of Policy Modeling, 38(1), 166-180.

PRATAMA POETRA, R. O. N. A. L. D. (2016). Pengaruh Inflasi, Harga Minyak Mentah, Suku Bunga, Nilai Tukar Rupiah Terhadap Indeks Harga Saham
Gabungan (Ihsg) Di Bursa Efek Indonesia. Jurnal Pendidikan Ekonomi (JUPE), 4(3).

Sari, R., Hammoudeh, S., Soytas, U., 2010. Dynamics of oil price, preciousmetall prices, and exchange rate. Energy Econ. 32 (2), 351-362.

Sinton, J., 2014. An empirical investigation of the causa relationship between gold price, exchange rate changes and jakarta composite index. Proc. World Bus. Soc. Sci. Res. Conf. 1-10 Paris.

Sjaastad, L.A., Scaccivillani, F., 1996. The price of gold and the exchange rate. J. Int. Money Financ. 15 (6), 879-897.

Sjaastad, L.A., 2008. The price of gold and the exchange rate once again. Resour. Pol. 33 (2), 118-124.

Srinivasan, P., Prakasam, K., 2015. Gold price, stock price and exchange rate nexus: the case of India. Rom. Econ. J. 77-94.

Sujit, K.S., Kumar, B.R., 2011. Study on dynamic relationship among gold price, oil price, exchange rate and stock market returns. Int. J. Appl. Bus. Econ. Res. 9 (2), 145-165.

Sunariyah. (2011). Pengantar Pengetahuan Pasar Modal (Edisi ke-6). Yogyakarta: UPP STIM YKPN. 
204AGREGAT: Jurnal Ekonomi dan Bisnis

Vol. 3, No. 2, September 2019

http://journal.uhamka.ac.id/index.php/agregat

p-ISSN: 2549-5658 e-ISSN: 2549-7243

DOI: 10.22236/agregat_vol3/is2pp191-204

Hal 191-204

Turhan, M.I., Sensoy, A., \& Hacihasanoglu, E. (2014).A comparative analysis of the dynamic relationship between oil prices and exchange rates. Journal of

International Financial Markets,

Kurs Rupiah, Indeks Nikkei 225, dan

Institutions and Money, 32, 397-414.

Yahyazadehfar, M., Babaie, A., 2012.

Wang, K.M., Lee, Y.M., 2011. The yen for Macroeconomic variables and stock price: gold. Resour. Pol. 36 (1), 39-48.

Witjaksono, A. A. (2010). Analisis Pengaruh new evidence from Iran. Middle East J.

Tingkat Suku Bunga SBI, Harga

Minyak Dunia, Harga Emas Dunia, 